The INL is a

U.S. Department of Energy

National Laboratory

operated by

Battelle Energy Alliance

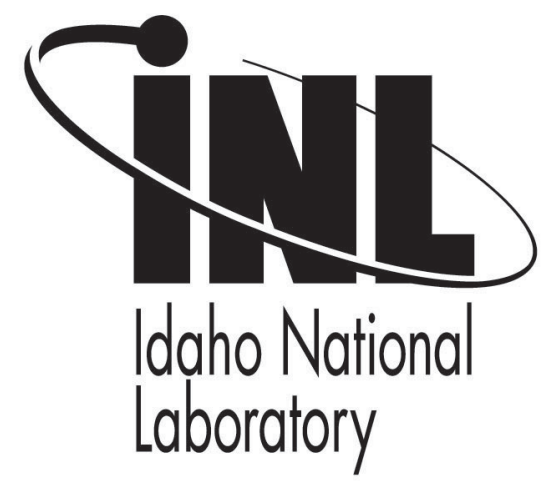

\title{
Characterization of Irradiated Metal Waste from the Pyrometallurgical Treatment of Used EBR-II Fuel
}

TMS Annual Conference

Brian R. Westphal

S. M. Frank

W. M. McCartin

D. G. Cummings

J. J. Giglio

T. P. O'Holleran

P. A. Hahn

T. S. Yoo

K. C. Marsden

K. J. Bateman

M. N. Patterson

March 2013
This is a preprint of a paper intended for publication in a journal or proceedings. Since changes may be made before publication, this preprint should not be cited or reproduced without permission of the author. This document was prepared as an account of work sponsored by an agency of the United States Government. Neither the United States Government nor any agency thereof, or any of their employees, makes any warranty, expressed or implied, or assumes any legal liability or responsibility for any third party's use, or the results of such use, of any information, apparatus, product or process disclosed in this report, or represents that its use by such third party would not infringe privately owned rights. The views expressed in this paper are not necessarily those of the United States Government or the sponsoring agency. 


\title{
Characterization of Irradiated Metal Waste from the Pyrometallurgical Treatment of Used EBR-II Fuel
}

\author{
BRIAN R. WESTPHAL, S.M. FRANK, W.M. MCCARTIN, D.G. CUMMINGS, \\ J.J. GIGLIO, T.P. O'HOLLERAN, P.A. HAHN, T.S. YOO, K.C. MARSDEN, \\ K.J. BATEMAN, and M.N. PATTERSON
}

As part of the pyrometallurgical treatment of used Experimental Breeder Reactor-II fuel, a metal waste stream is generated consisting primarily of cladding hulls laden with fission products noble to the electrorefining process. Consolidation by melting at high temperature $\left[1873 \mathrm{~K}\left(1600{ }^{\circ} \mathrm{C}\right)\right]$ has been developed to sequester the noble metal fission products $(\mathrm{Zr}$, Mo, $\mathrm{Tc}, \mathrm{Ru}, \mathrm{Rh}, \mathrm{Te}$, and $\mathrm{Pd}$ ) which remain in the iron-based cladding hulls. Zirconium from the uranium fuel alloy (U-10Zr) is also deposited on the hulls and forms Fe-Zr intermetallics which incorporate the noble metals as well as residual actinides during processing. Hence, $\mathrm{Zr}$ has been chosen as the primary indicator for consistency of the metal waste. Recently, the first production-scale metal waste ingot was generated and sampled to monitor $\mathrm{Zr}$ content for $\mathrm{Fe}-\mathrm{Zr}$ intermetallic phase formation and validation of processing conditions. Chemical assay of the metal waste ingot revealed a homogeneous distribution of the noble metal fission products as well as the primary fuel constituents $\mathrm{U}$ and $\mathrm{Zr}$. Microstructural characterization of the ingot confirmed the immobilization of the noble metals in the Fe- $\mathrm{Zr}$ intermetallic phase.

\section{INTRODUCTION}

BEGINNING with the development of melt refining as a reprocessing technology for metallic nuclear fuel, process engineers have strived to simplify the reprocessing flow sheet while still achieving sufficient recoveries with minimal waste accumulation. ${ }^{[1]}$ Melt refining marked the transition from a laboratory-based recovery method to an engineering-scale process while utilizing non-aqueous techniques. With simplicity as the cornerstone, pyrometallurgical reprocessing techniques like melt refining have attracted considerable interest in the nuclear community for the last 50 years. Combining the benefits of pyrometallurgical techniques with electrochemistry, the integral fast reactor (IFR) concept enhanced the reprocessing of used nuclear fuel considerably. ${ }^{[2,3]}$ Keeping it simple, the IFR concept employs only two waste streams; a ceramic-based and a metalbased one depending on the reactivity of the separated fuel constituents. ${ }^{[4]}$ Those separated constituents that are not reactive to the electrochemical salts are considered noble and are primarily retained by the fuel cladding following electrochemical operations. ${ }^{[5,6]}$ The metal waste stream therefore consists of noble metal fission products such as zirconium $(\mathrm{Zr})$, molybdenum (Mo), ruthenium $(\mathrm{Ru})$, rhodium $(\mathrm{Rh})$, technetium $(\mathrm{Tc})$,

BRIAN R. WESTPHAL, W.M. MCCARTIN, T.P. O'HOLLERAN, T.S. YOO, K.C. MARSDEN, K.J. BATEMAN, and M.N. PATTERSON, Engineers, S.M. FRANK, D.G. CUMMINGS, J.J. GIGLIO, and P.A. HAHN, Chemists, are with the Idaho National Laboratory, P.O. Box 1625, Idaho Falls, ID 83415. Contact e-mail: brian.westphal@inl.gov

Manuscript submitted May 9, 2013. palladium (Pd), and tellurium (Te) as well as the iron (Fe)-based cladding. The cladding hulls also contain adhering salt and a minor amount of unreacted residual fuel, primarily $\mathrm{Zr}$ if the fuel is a uranium (U)- $10 \mathrm{Zr}$ (wt pct) binary alloy due to the relative thermochemical stabilities of $\mathrm{Zr}$ and $\mathrm{U}$ in the electrolyte. ${ }^{[7]} \mathrm{It}$ is for this reason that an $\mathrm{Fe}-\mathrm{Zr}$ alloy was defined for the metal waste stream. ${ }^{[8]} \mathrm{A}$ composition of $15 \mathrm{wt}$ pct $\mathrm{Zr}$ is targeted for ease of processing and may require trim $\mathrm{Zr}$ as an additive if sufficient $\mathrm{Zr}$ is not available as fuel residual.

Development of the metal waste form has progressed from the initial surrogate test program ${ }^{[8,9]}$ to production-scale irradiated operations and includes compositional and microstructural evaluations for phase stability, ${ }^{[10-25]}$ corrosion testing, ${ }^{[26-33]}$ mechanical as well as thermophysical property testing, and process qualification. ${ }^{[34,35]}$ As a result of the extensive developmental test program, the following conclusions can be stated: (1) the intermetallic $\mathrm{ZrFe}_{2}$ phase incorporates the noble metals and actinides exclusively, with the exception of technetium which may also be present in the iron solid solution, (2) the metal waste alloy is as corrosion resistant as borosilicate glass based on a variety of durability tests including immersion, electrochemical, galvanic, hydration, and toxicity, and (3) the alloy is a viable high-level waste form for geological disposal despite the recent delay in repository licensing.

Recently, the first production-scale irradiated metal waste ingot was characterized for product consistency by both a chemical assay and a metallographic technique. Since $\mathrm{Zr}$ was selected to monitor the consistency of the metal waste form with respect to regulatory 
requirements and process conditions, its presence and distribution are vital to the formation of $\mathrm{Fe}-\mathrm{Zr}$ intermetallics and, thus, the sequestration of fuel constituents. ${ }^{[29]} \mathrm{A} \mathrm{Zr}$ content between 5 and $20 \mathrm{wt}$ pct is specified to assure sufficient intermetallic phase formation and yet account for localized variations beyond the base composition of $15 \mathrm{wt}$ pct $\mathrm{Zr}$. A consistent $\mathrm{Zr}$ content also verifies that the operating parameters, viz., time and temperature, are adequate to qualify the metal waste form process. ${ }^{[34]}$

The secondary and perhaps more important reason for characterizing the metal waste stream in light of the current repository situation is material accountancy. Tracking of accountable nuclear materials during the pyrometallurgical treatment of used Experimental Breeder Reactor-II (EBR-II) fuel is required as a contractor to the Department of Energy (DOE). ${ }^{[36]}$ Since the accountable material remaining in the cladding waste stream has not been accurately measured via sampling efforts to date, characterizing the metal waste products fulfills the requirements of material accountancy during the EBR-II pyrometallurgical process. Coincidentally, the metal waste stream is the final remaining stream of the process where material accountancy is lacking.

Given in the following sections are descriptions of the experimental equipment and operations including sampling and analyses, presentation of the chemical as well as the metallographic results, and conclusions regarding the homogeneity and consistency of the metal waste form.

\section{EXPERIMENTAL}

\section{A. Equipment and Operations}

A layout of the production metal waste equipment including crucible assembly, induction coil, condenser, and associated instrumentation is shown in Figure 1. The furnace region of the equipment is heated by a passively cooled induction coil connected to a $50 \mathrm{~kW}$ power supply and capable of $1973 \mathrm{~K}\left(1700{ }^{\circ} \mathrm{C}\right)$. A vacuum system is connected to the sealed condenser and crucible regions allowing a differential pressure to be achieved relative to the coil region, thus protecting the coil from deleterious salt vapors. Operating experience has shown that a vacuum less than $133 \mathrm{~Pa}$ is unrealistic due to the inherent sealing characteristics of the equipment even though the vacuum pump attached to the metal waste equipment is capable of $27 \mathrm{~Pa}$. A more detailed description of the induction and vacuum systems can be found in Reference 34 .

During operation, salt distillate is transferred from the crucible assembly to the condenser region in the vapor phase due to differential temperature and pressure gradients. The graphite crucible assembly is a two-piece composite design to facilitate multi-use handling of process materials with a usable volume of $\sim 75 \mathrm{~L}$. Since the cladding hulls are low in bulk density, the large volume of the assembly maximizes loading. For ingot unloading, the upper crucible ring is separated from the lower crucible bottom so that dumping can be

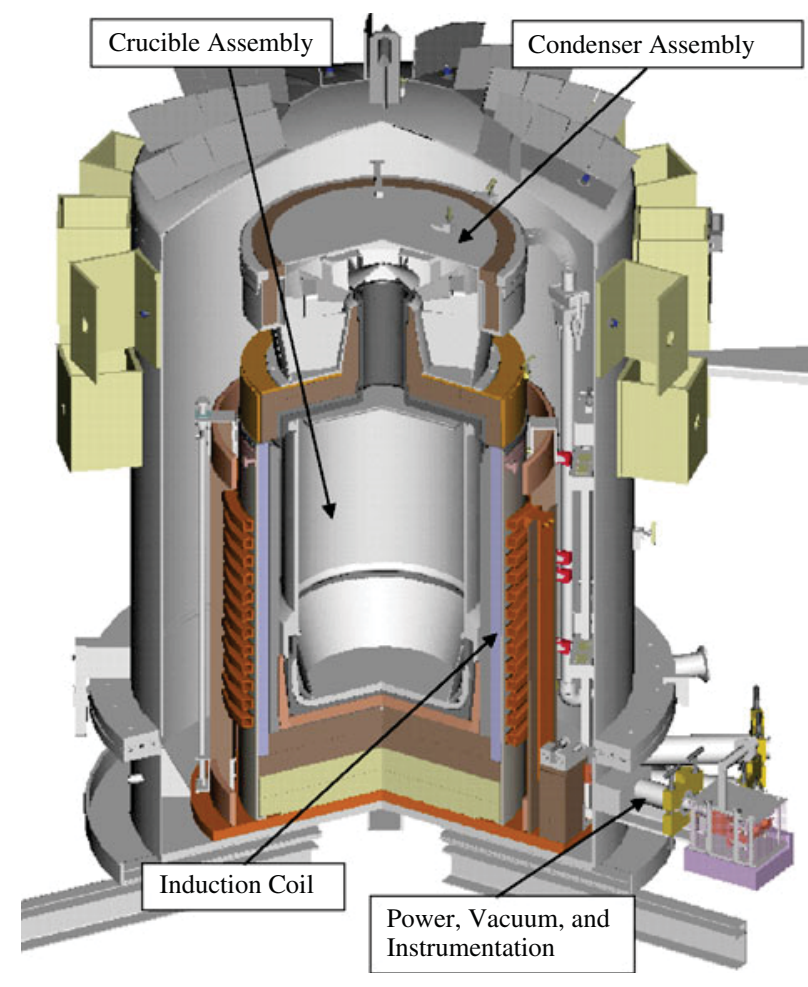

Fig. 1-Schematic of production-scale metal waste equipment.

performed. Both crucible sections are lined with an alumina refractory to prevent the reactive process materials from contact with the graphite assembly. Additionally, a thin sacrificial stainless steel liner is utilized to minimize the interaction of alumina with salt. The stainless steel condenser mates to the top of the crucible assembly and distillate flows into the annular zone of the condenser by a cylindrical graphite throat. Removal of the salt from the condenser is assisted by dividers which direct the condensed material into pieshaped pieces. As designed, the crucible bottom and condenser have a capacity of $90-\mathrm{kg}$ metal and $25-\mathrm{kg}$ salt, respectively.

Due to its radioactive nature, the processing of metal waste must be performed in a shielded hot cell environment. The production-scale distillation and consolidation operations for metal waste processing are conducted in the Hot Fuel Examination Facility (HFEF) at the Materials and Fuels Complex of the Idaho National Laboratory (INL). Historically, this facility has been utilized for post-irradiation examinations of fast reactor fuels, but more recently has diversified to other research and development programs requiring hot cell capabilities. The metal waste equipment resides in the argon atmosphere cell of the HFEF to minimize contamination of process materials with oxygen and water vapor. All handling operations in the HFEF hot cell are performed by remote mechanical manipulators as well as overhead cranes.

For the first production-scale metal waste run, $57.5 \mathrm{~kg}$ of salt-laden cladding hulls from six electrorefining batches were charged into a $1.8-\mathrm{kg}$ stainless steel liner which was then loaded into the two-piece crucible 
assembly. Based on non-representative hull sampling following electrorefining, the final $\mathrm{Zr}$ content of the hulls was projected to be sufficient for meeting the 5 to 20 wt pet specification; thus, no trim $\mathrm{Zr}$ was added. The operating conditions as recorded by thermocouples and pressure sensors are shown in Figure 2. Two temperature readings are shown in Figure 2: the temperature from the side of the crucible, which controls the furnace, and from the bottom of the crucible near the ingot. The three phases or plateaus on the crucible side data are for sodium oxidation (if present, which for this run was not applicable), salt distillation, and metal consolidation. A power interruption was experienced at $\sim 225$ minutes as can be seen on Figure 2, but had only a minor effect on the crucible bottom temperature. The crucible bottom or ingot region reached $1873 \mathrm{~K}\left(1600{ }^{\circ} \mathrm{C}\right)$ for $\sim 1$ hour. The start of salt distillation is indicated on the condenser throat thermocouple readings as well as the condenser pressure sensors at $\sim 240$ minutes. It appears that salt distillation was nearing completion during the final increase of temperature to consolidation temperatures.

Following an adequate cooldown period, the first production-scale metal waste ingot (Figure 3) was unloaded from the crucible bottom and drill sampled using a remotized drill press located in the HFEF. The approximate dimensions of the ingot are $40 \mathrm{~cm}$ in diameter and $5 \mathrm{~cm}$ in height. Three radial locations from the edge of the ingot toward the middle (locations 1 through 3) were sampled at three axial positions (top, center, and bottom) with the exception of the second hole where only a bottom and center sample were taken.
Sampling was performed by initially drilling $\sim 0.5 \mathrm{~cm}$ into the bottom of the ingot, removing the metal fines, and taking axial samples with $\sim 0.5 \mathrm{~cm}$ between samples. The particle size of the metal fines was generally less than $1 \mathrm{~mm}$ and $\sim 0.5 \mathrm{~g}$ of material was acquired for each sample. The two samples for metallographic analyses were taken of the fines from the edge and middle radial locations, embedded in a sample mount with epoxy, and polished to 1200 grit with $\mathrm{SiC}$.

\section{B. Characterization}

Upon receipt of the samples in the Analytical Laboratory, the metal fines were dissolved in a solution of $3: 1$ concentrated hydrogen chloride $(\mathrm{HCl})$ and nitric acid $\left(\mathrm{HNO}_{3}\right)$ with 2 vol pct concentrated hydrogen fluoride (HF). Approximately $20 \mathrm{~mL}$ of solution is sufficient for complete dissolution of the 0.5-g samples which is then diluted with demineralized water to $100 \mathrm{~mL}$ for analyses. For chemical analyses, several different techniques were utilized for the determination of chemical compositions, namely, inductively coupled plasma mass spectroscopy (ICP-MS), inductively coupled plasma atomic emission spectroscopy (ICP-AES), and gamma-ray spectroscopy. A VG Plasma Quad 3-Nuclide (Thermo Fisher Scientific Inc., Waltham, MA) instrument was utilized for ICP-MS, while a Prodigy (Teledyne Leeman Labs, Hudson, NY) instrument was used for ICP-AES. The equipment for these techniques has been modified for use with radioactive samples to limit personnel exposure by operation of the

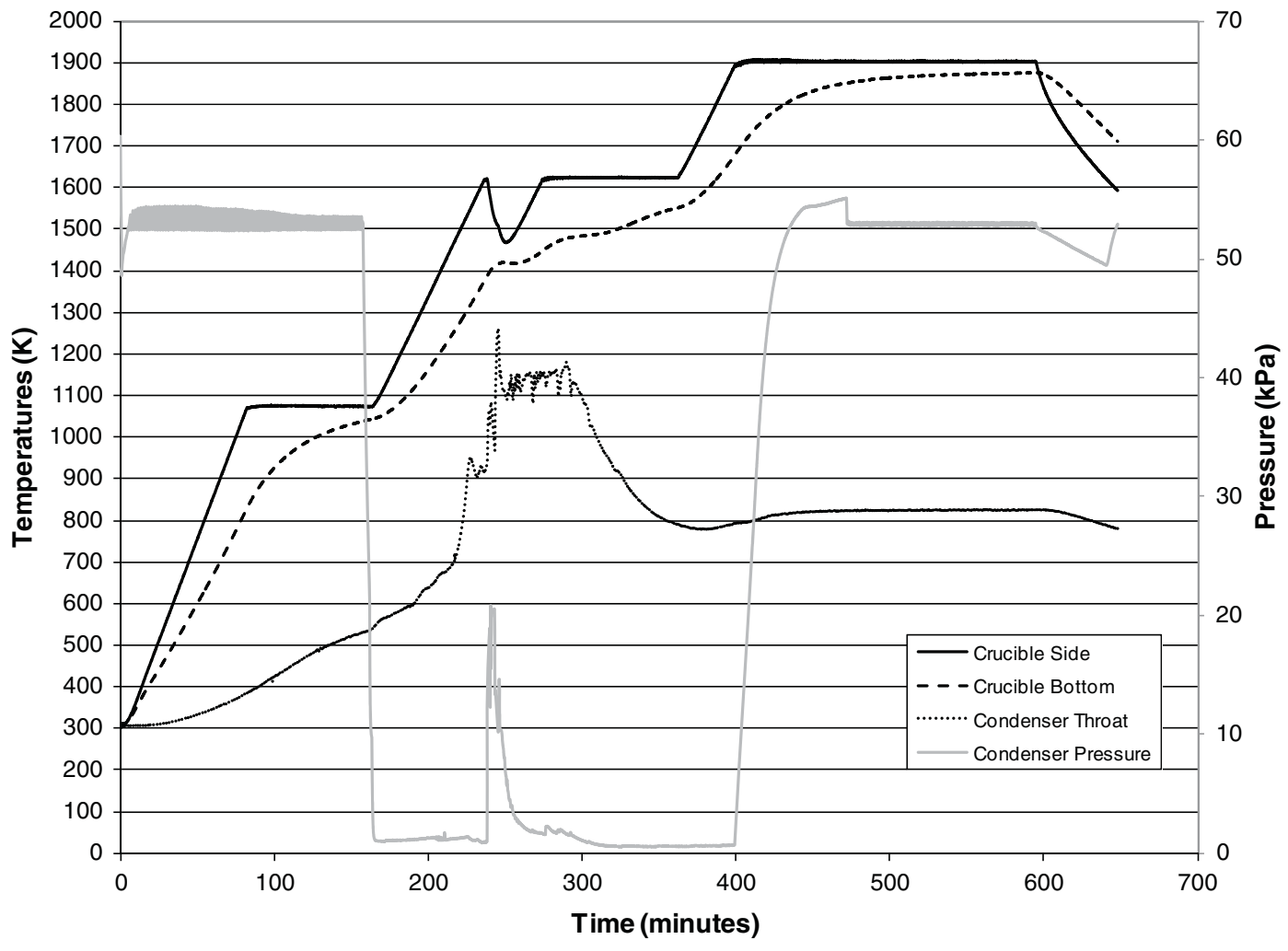

Fig. 2-Operating conditions for first production-scale metal waste run. 


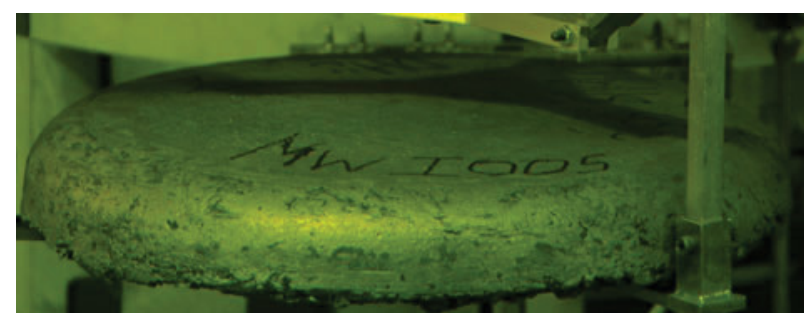

Fig. 3-Ingot from first production-scale metal waste run.

plasma in a shielded glovebox and monitoring of the transmission by a spectrometer located exterior to the box. For the metallography, scanning electron microanalysis (SEM) was performed using a JEOL JSM7600F (JEOL USA, Inc, Peabody, MA) electron microscope equipped with an energy/wavelength-dispersive Xray spectrometer (EDS/WDS) and INCA software (Oxford Instruments, Oxfordshire, UK). The EDS/ WDS capability allows the generation of backscattered and secondary electron images, semi-quantitative point to point compositional analysis (EDS), and X-ray mapping (WDS).

\section{RESULTS AND DISCUSSION}

Following unloading of the metal waste ingot, mass measurements were performed on the ingot as well as the salt in the condenser. The ingot weighed approximately $43.2 \mathrm{~kg}$, while the condenser gained $16.1 \mathrm{~kg}$. The chemical and metallographic analysis results from sampling of the metal waste ingot are presented in the following sections.

\section{A. Chemical}

Shown in Table I are the analytical chemistry results, both elemental and isotopic, for the eight samples taken from the first production-scale metal waste ingot. In a few cases, specifically for Pd and Te, the elemental values shown are the sum of the isotopic contributions. With the exception of Cs-137 which is from gamma spectroscopy, the isotopic data are a result of ICP-MS analyses. The remaining elemental data are from ICPAES analyses. Also included in the table are averaged values with the relative standard deviations (RSD) on the samples and the total mass balance of constituents analyzed.

Although not as high as anticipated, the $\mathrm{Zr}$ levels are within the 5 to $20 \mathrm{wt}$ pct range which should allow sufficient formation of iron intermetallic for the incorporation of noble metals to assure product consistency. Also, the standard deviation of the $\mathrm{Zr}$ is small indicating low variability between the samples. The second significant result from the data is that the total mass balances are very close to unity implying that all the metal waste constituents were recognized and analyzed.

Depicted in Figures 4, 5, 6, and 7 are the averaged data of the radial and axial locations for the major and minor constituents given in Table I. The major constituents consist of steel-related elements $(\mathrm{Fe}, \mathrm{Cr}$,

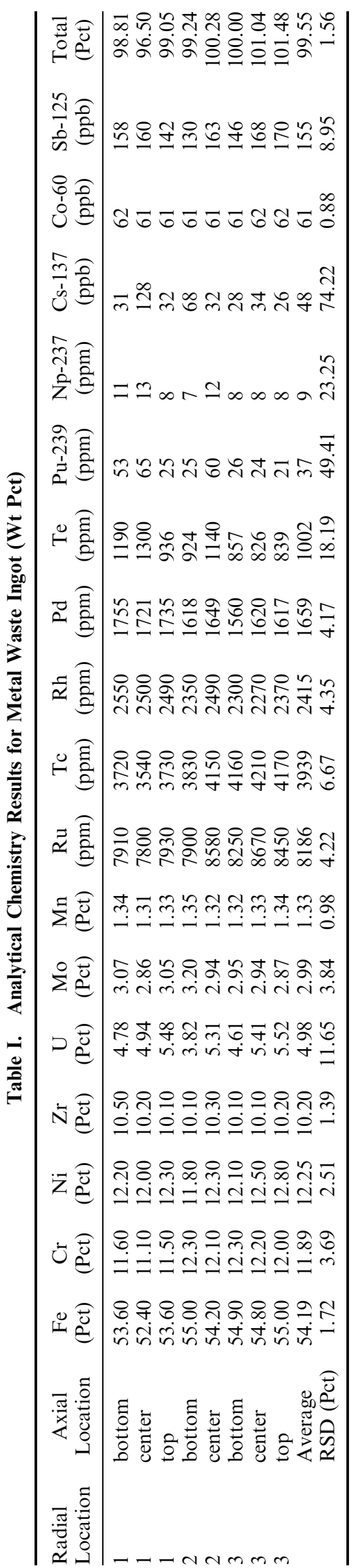




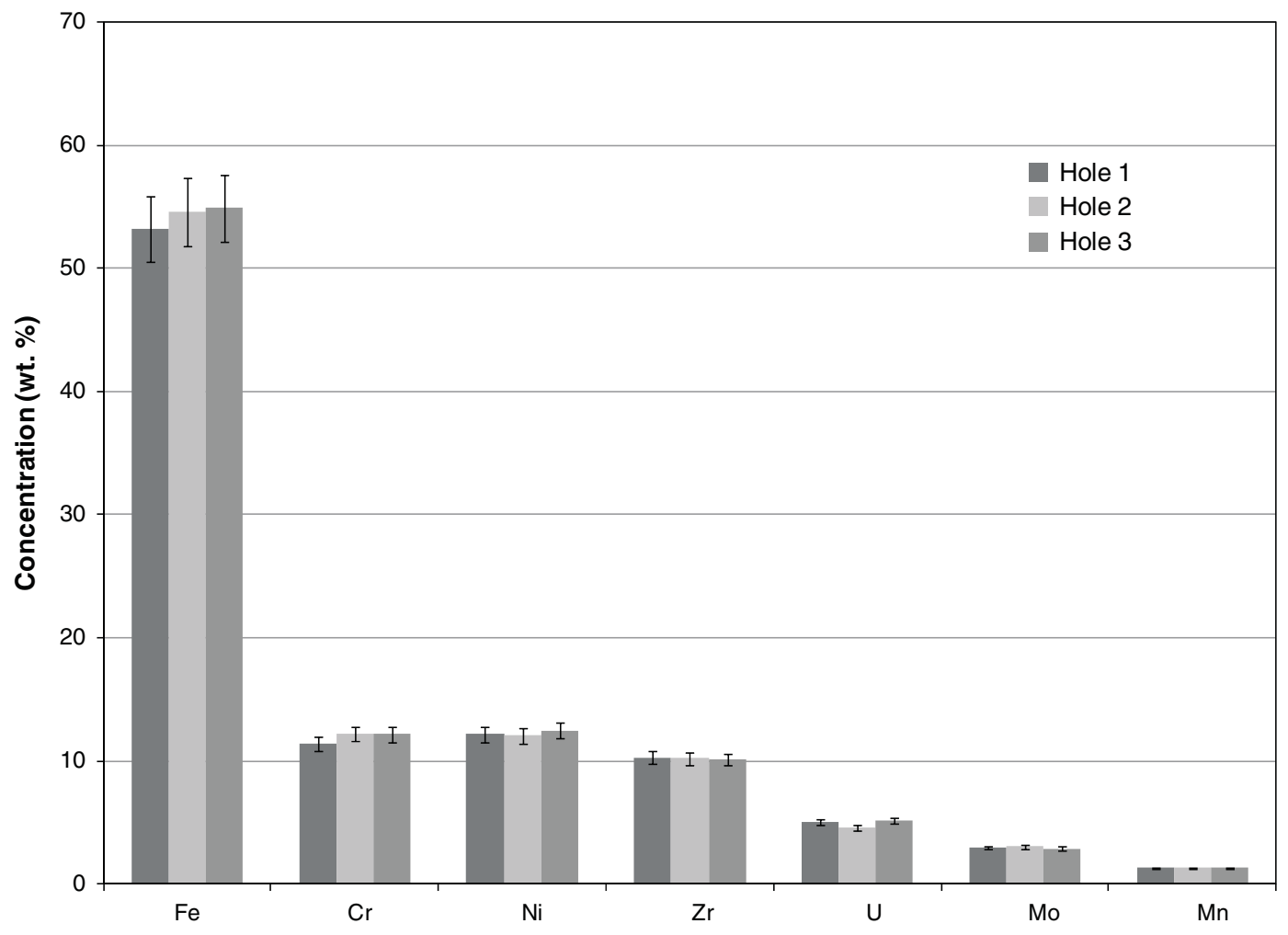

Fig. 4 - Radial comparison of major constituents analyzed in the metal waste ingot.

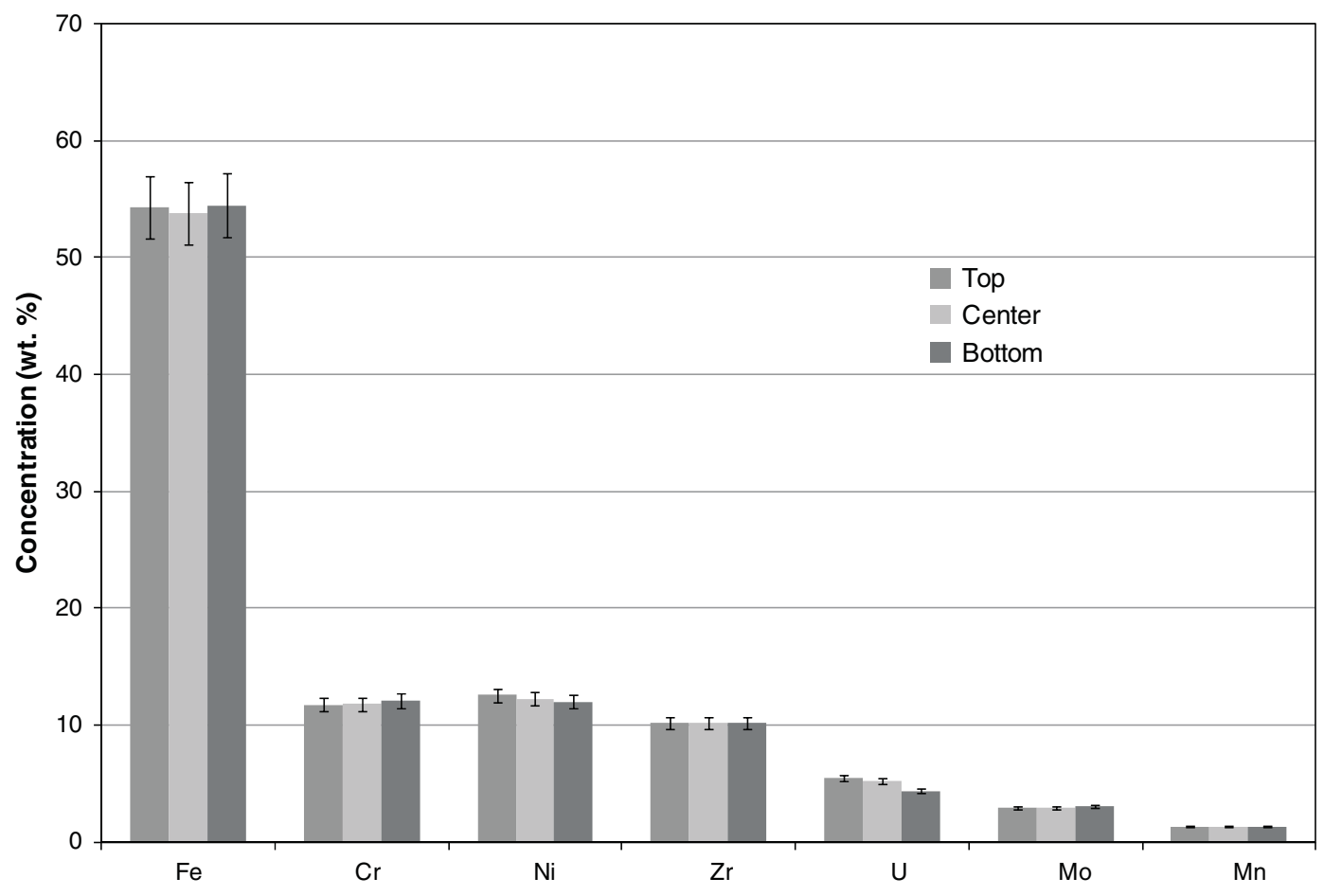

Fig. 5-Axial comparison of major constituents analyzed in the metal waste ingot.

$\mathrm{Ni}, \mathrm{Mo}$, and $\mathrm{Mn}$ ) as well as $\mathrm{Zr}$ and $\mathrm{U}$. The minor constituents include the noble metals $(\mathrm{Ru}, \mathrm{Tc}, \mathrm{Rh}, \mathrm{Pd}$, and Te). Also included in Figures 4, 5, 6, and 7 are the error bars for the measurement uncertainties at one sigma in the constituent analyses. For both the major and minor constituents, no statistically significant trends outside the error of the measurements are seen in the data. For the fission product noble metals $(\mathrm{Ru}, \mathrm{Tc}, \mathrm{Rh}$, 


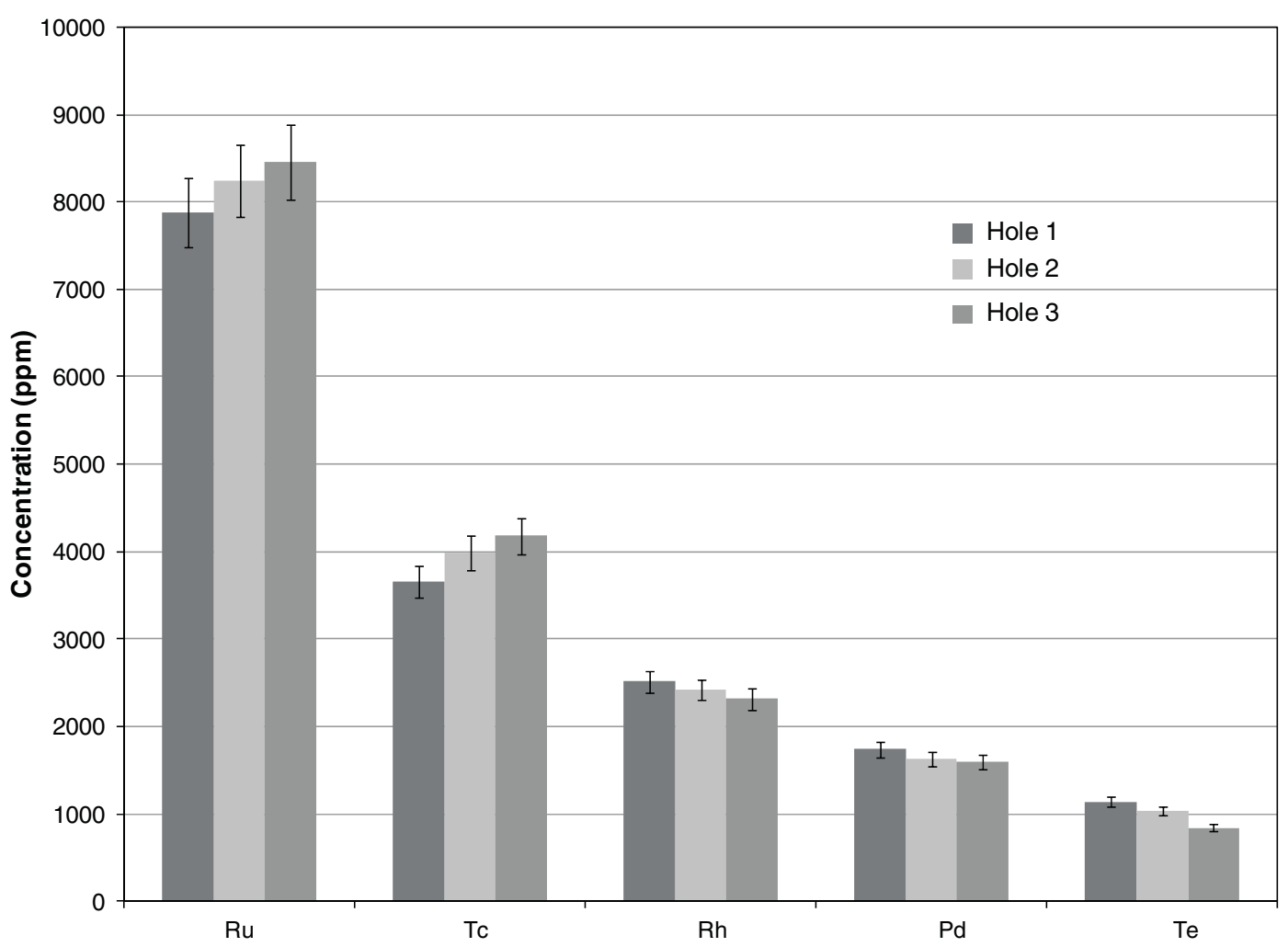

Fig. 6-Radial comparison of minor constituents analyzed in the metal waste ingot.

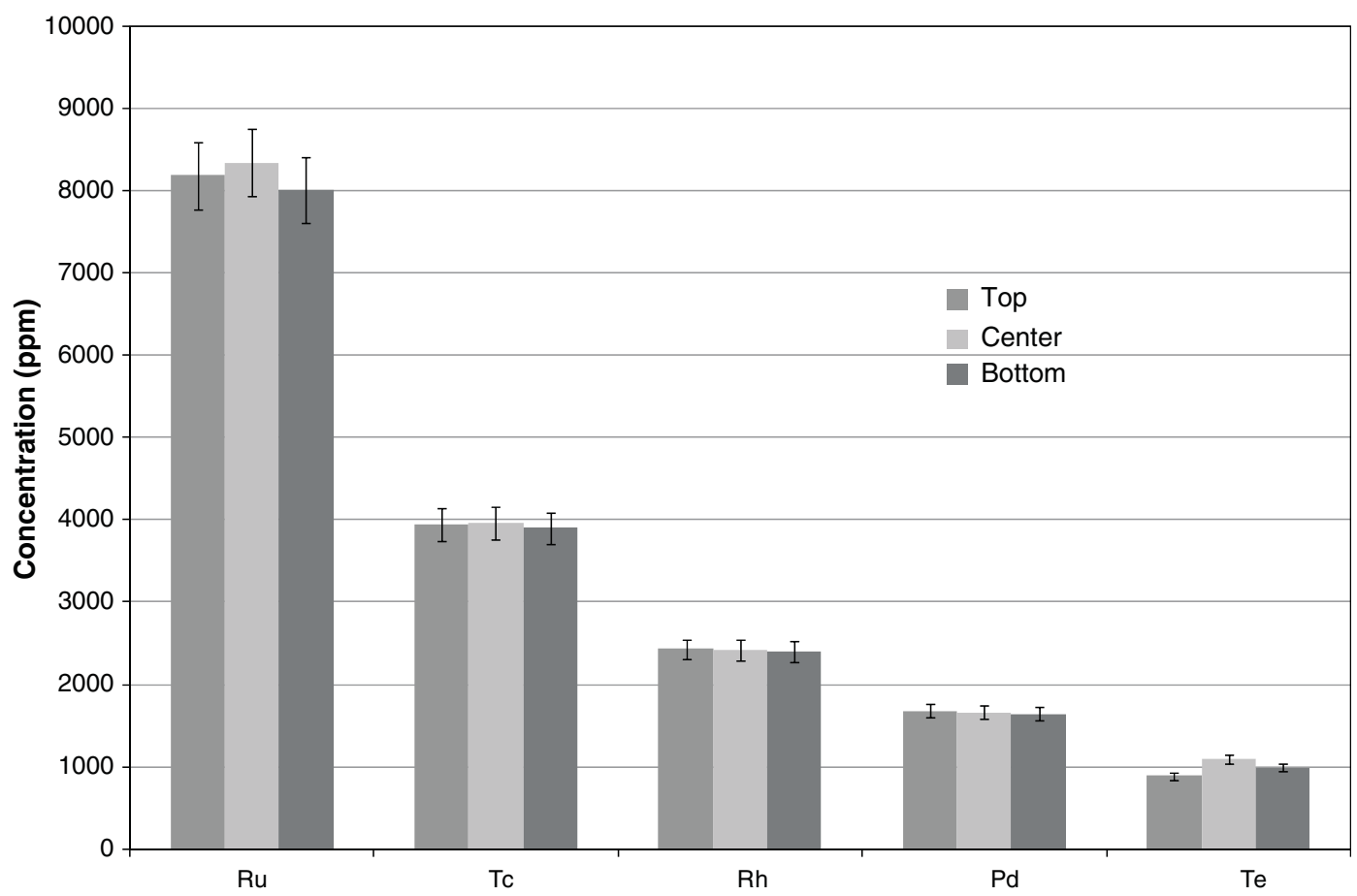

Fig. 7-Axial comparison of minor constituents analyzed in the metal waste ingot.

$\mathrm{Pd}$, and to some extent $\mathrm{Zr}$ and Mo since they are also associated with fuel and steel), the variabilities, as indicated by standard deviations, within the samples are all less than 7 pet indicating a consistent distribution of the noble metals in the ingot.

Although detected in only trace quantities, the presence of neptunium $(\mathrm{Np}-237)$ and plutonium $(\mathrm{Pu}-239)$ in 
the samples (Table I) was expected based on the presence of residual fuel alloy ( $\mathrm{U}$ and $\mathrm{Zr}$ ) and previous chemical analyses of irradiated metal waste ingots. ${ }^{[29]}$ The ratio of $\mathrm{U}$ to $\mathrm{Pu}$ in the metal waste samples is significantly different compared to that in the fuel $(\sim 200)$ due to the preferential oxidation of $\mathrm{Pu}$ to the electrorefiner salt. For the gamma-emitting isotopes detected (Cs-137, Sb-125, and Co-60), Sb-125 and Co-60 are considered noble and are fission and activation products, respectively. Their distribution in the metal waste samples is consistent with the other noble metals. Cesium, on the other hand, is not noble to the electrorefiner salts, thus its presence in the samples either signifies undistilled salt or possibly cross-contamination from the hot cell. Assuming the Cs-137 is from incomplete distillation, the detection capability of gamma spectroscopy is such that quantification of removal by distillation is possible and yields a value of $\sim 99.99$ pct. The primary salt constituents $(\mathrm{Li}, \mathrm{K}$, and $\mathrm{Na}$ ) and $\mathrm{Cd}$ were also analyzed in the samples, but fell short of the quantification capability of the ICP-AES. For Cd, the typical limits of quantification for ICP-AES on these samples were 50 to $100 \mathrm{ppm}$.

Using the measured data for $\mathrm{Mo}, \mathrm{Ru}, \mathrm{Tc}, \mathrm{Rh}, \mathrm{Pd}$, and Te from Table I, a comparison can be made with an amount calculated from fission yield to assess the relative abundance of the noble metals in the metal waste ingot (Figure 8). Since Mo is present in metal waste as both steel alloy and fission product, an alloy content of $1.75 \mathrm{wt}$ pct was assumed, based on the cladding hulls being a mixture of 316SS (2.0 wt pct) and D9 (1.5 wt pct), in order to calculate the fission product contribution. Fission yield data are for a fast spectrum based on the fission of U-235 into specific mass numbers. ${ }^{[37]}$ Since several of the noble metals (Mo, $\mathrm{Ru}, \mathrm{Pd}$, and $\mathrm{Te}$ ) are multi-isotopic, the individual isotopes were weighted for the calculated data. As can be seen, an excellent correlation exists for all the noble metals except $\mathrm{Te}$, particularly considering the measurement uncertainties as shown by the error bars. The combination of the five primary noble metal (Mo, Ru, $\mathrm{Tc}, \mathrm{Rh}$, and $\mathrm{Pd}$ ) fission products has been recognized in oxide fuels and appears to also be a stable distinct phase in metallic fuels. ${ }^{[38]}$ The behavior of Te is not surprising given its non-metallic tendencies and reactivity with

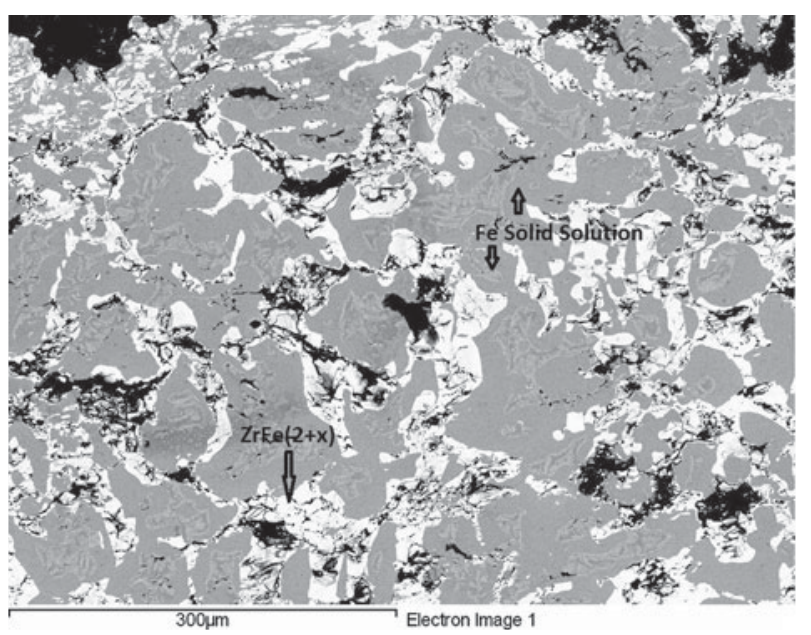

Fig. 9-Low-magnification, backscattered electron (BSE) image of the edge radial location from the metal waste ingot.

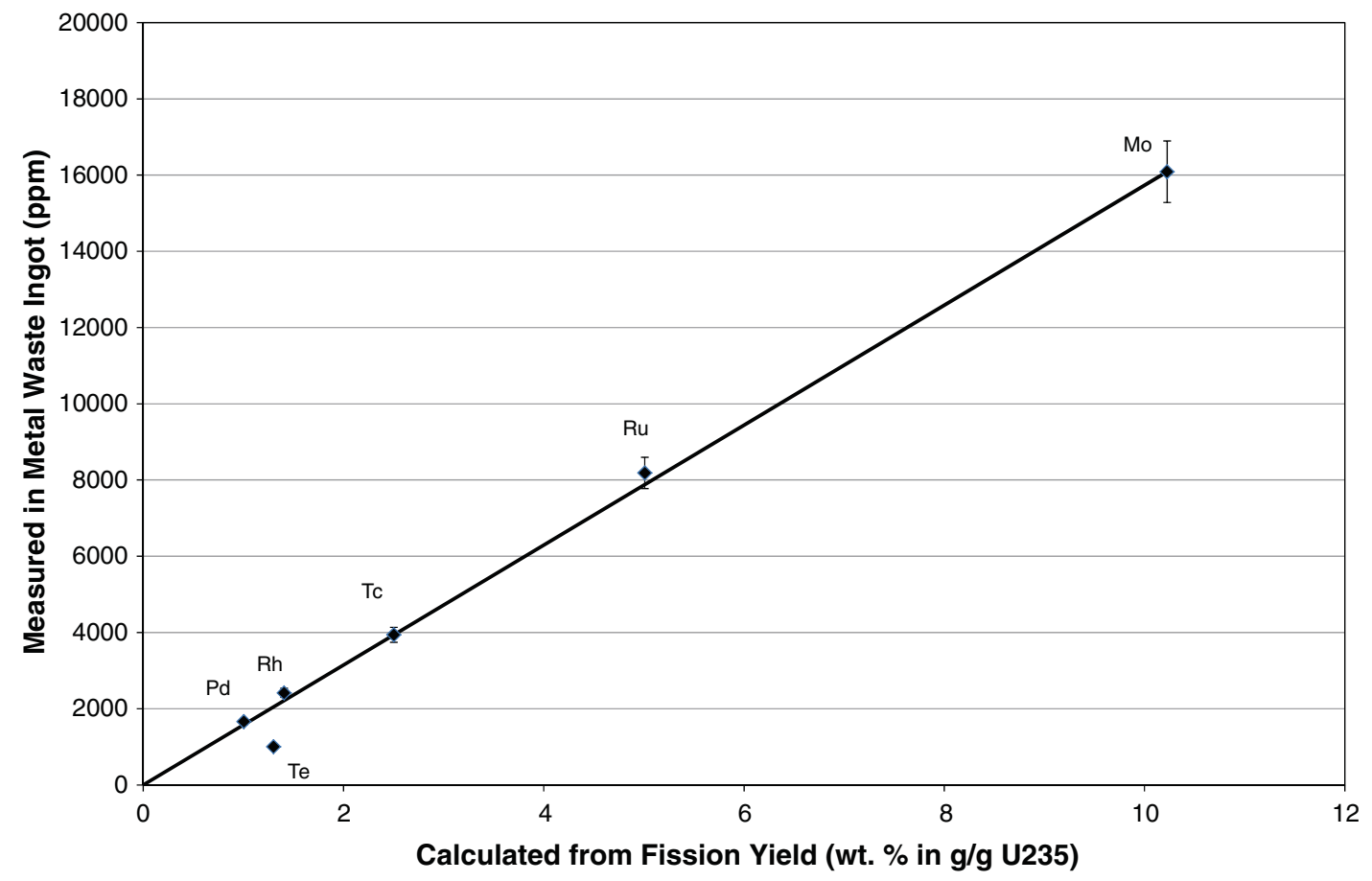

Fig. 8 - Comparison of calculated and measured data for noble metal content of the metal waste ingot. 
fission product cesium and zirconium. ${ }^{[38]}$ Approximately 50 pct of the calculated Te was quantified in the metal waste ingot.
Considering that $\mathrm{Zr}$ was chosen to monitor the consistency of the metal waste and $U$ analyses allow accountancy of nuclear materials, a student $t$ distribution

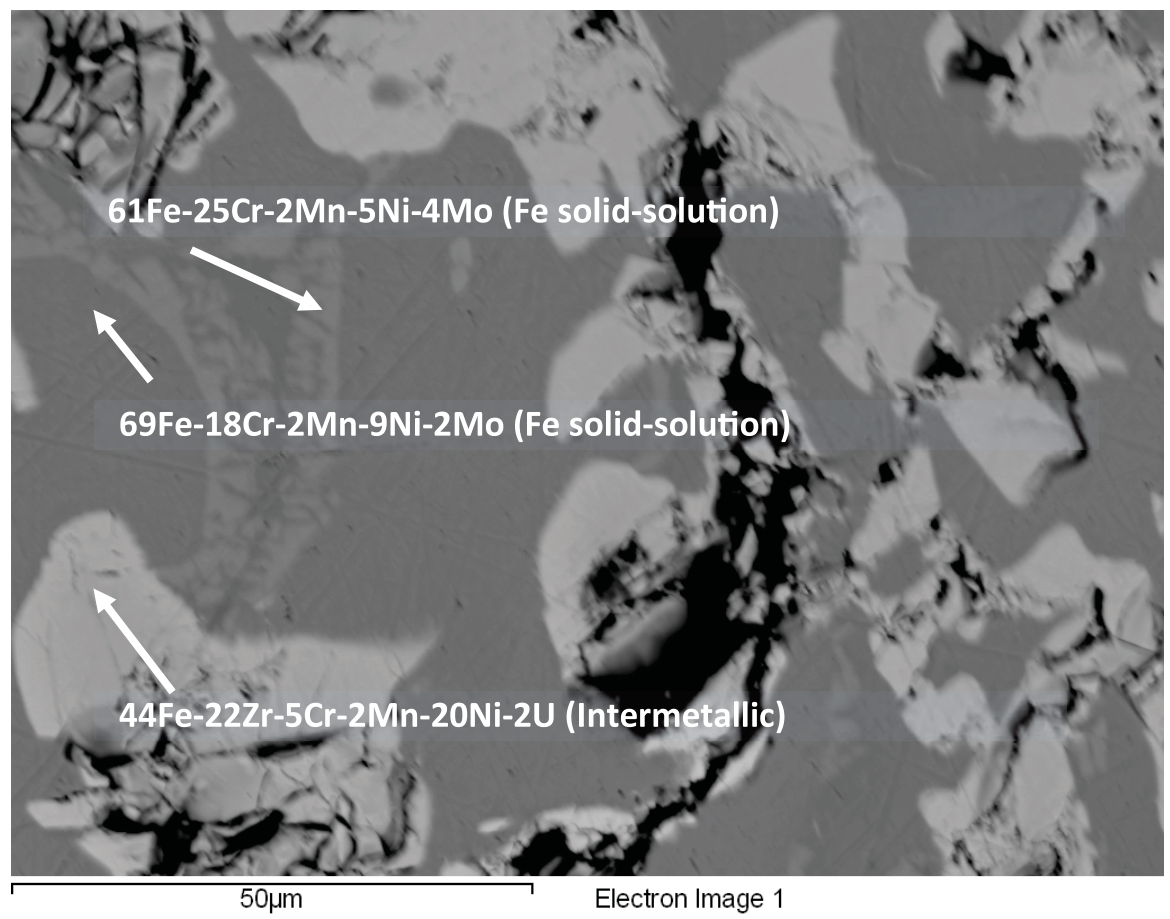

(a)
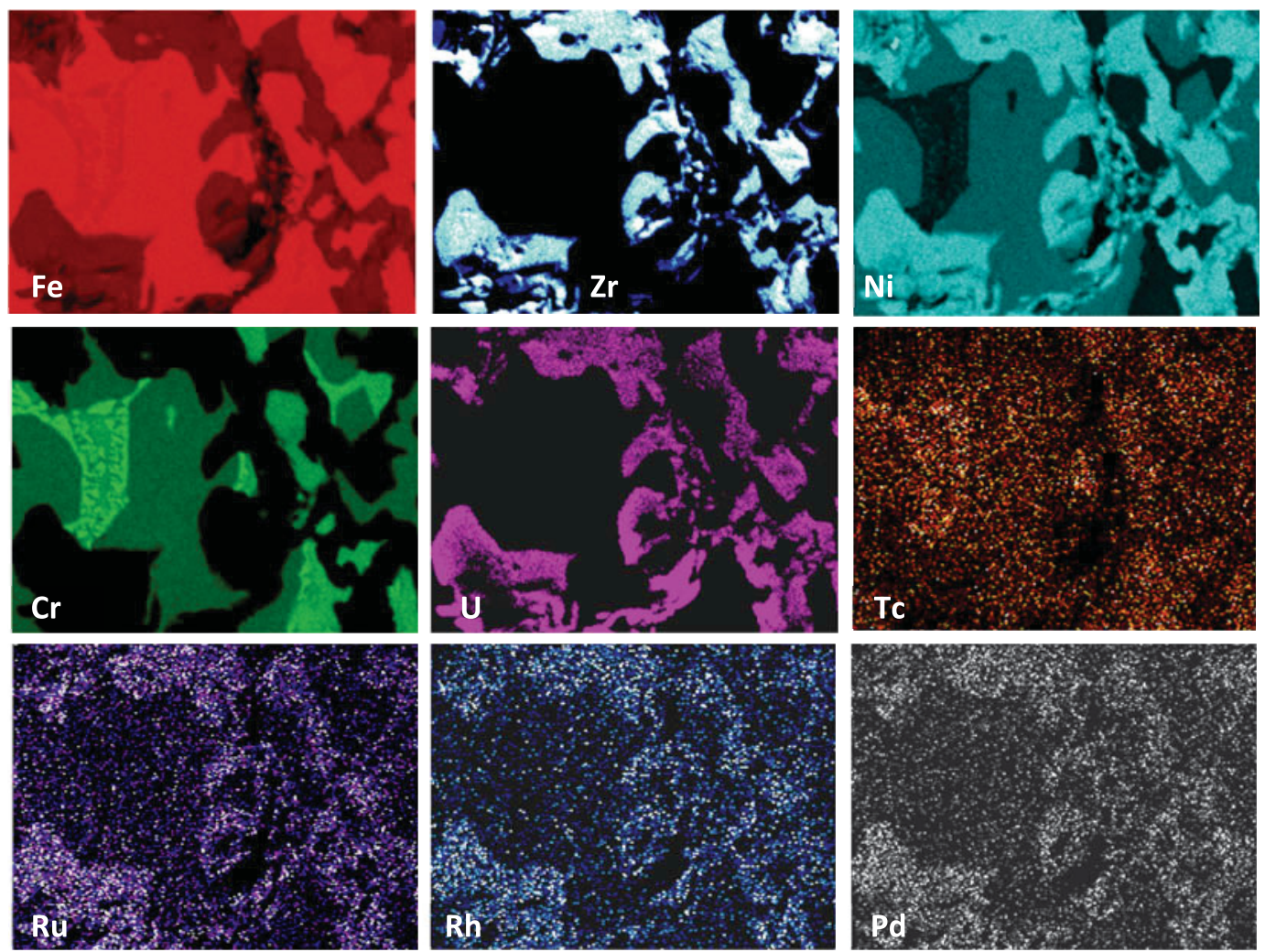

(b)

Fig. 10-(a). High-magnification BSE image of the middle radial location from the metal waste ingot. (b) WDS elemental X-ray maps of region shown in (a). 
was performed on $\mathrm{Zr}$ and $\mathrm{U}$ to minimize future sampling efforts. ${ }^{[39]}$ The two scenarios investigated were three samples (top, center, and bottom) from the middle radial position and one sample (center) from the middle radial position. For three samples, there is no statistical difference or significance in the $\mathrm{Zr}$ or $\mathrm{U}$ composition measured from the middle radial position compared to the bulk composition of the ingot at the 90 pct confidence level. If only the center sample from hole \#3 is analyzed, there is no statistical significance in the $\mathrm{Zr}$ or $\mathrm{U}$ up to the 97.5 pct confidence level, or beyond two standard deviations of the bulk data. For both scenarios, the difference between the data and the averaged data from the eight samples (Table I) is divided by the standard deviation and compared to a probability distribution at the appropriate confidence level. The number of samples to be taken in future metal waste operations will depend on the allowable uncertainties necessary for nuclear material accountancy.

\section{B. Metallographic}

Microanalysis of the metal waste ingot fines indicated formation of the expected Fe-Zr intermetallic and $\mathrm{Fe}$ solid-solution phases in the stainless steel-Zr alloy. Figure 9 shows a low-magnification $(200 \times)$ micrograph of the ingot edge sample with the three predominate phases. The high-contrast or bright region shown in Figure 9 is the $\mathrm{Zr}(\mathrm{Fe}, \mathrm{Cr}, \mathrm{Ni})_{2+x}$ intermetallic phase and the two gray-contrast regions (one darker and the other lighter in the image) correspond to two Fe solid-solution phases. ${ }^{[17]}$ The black area in Figure 9 is the epoxy mounting material underlying the alloy.

Figure $10(\mathrm{a})$ shows a higher magnification $(1000 \times)$ micrograph of the ingot middle sample with the three phases identified in atomic percent composition for the major elemental components. Quantification of major elements was performed by EDS analysis. Elements at low concentration in the alloy, namely, the transition or noble metal fission products of $\mathrm{Tc}, \mathrm{Ru}, \mathrm{Rh}$, and $\mathrm{Pd}$, were of insufficient concentration to be quantified by EDS, but can be detected qualitatively by WDS. Total area phase composition analysis was performed on the middle sample, Figure 10(a), resulting in a phase composition of 55 pct for the $69 \mathrm{Fe}-18 \mathrm{Cr}-2 \mathrm{Mn}-$ $9 \mathrm{Ni}-2 \mathrm{Mo} \mathrm{Fe}$ solid-solution phase, 8 pct for the $61 \mathrm{Fe}-$ 25Cr-2Mn-5Ni-4Mo Fe solid-solution phase, and 37 pct for the $44 \mathrm{Fe}-22 \mathrm{Zr}-5 \mathrm{Cr}-2 \mathrm{Mn}-20 \mathrm{Ni}-2 \mathrm{U}$ intermetallic phase.

Figure 10(b) shows WDS X-ray maps for the elements $\mathrm{Cr}, \mathrm{Fe}, \mathrm{Ni}, \mathrm{Zr}, \mathrm{Tc}, \mathrm{Ru}, \mathrm{Rh}, \mathrm{Pd}$, and $\mathrm{U}$ for the same region shown in Figure 10(a). As can be seen in Figure 10(b), the majority of the noble metal fission products $(\mathrm{Ru}, \mathrm{Rh}$, and $\mathrm{Pd})$ and $\mathrm{U}$ partition to the intermetallic phase, whereas Tc is distributed primarily between the two Fe solid-solution phases. In summary, no difference in sample morphology or elemental composition distributions was observed between the ingot edge and middle samples indicating formation of a homogeneous alloy ingot.

\section{CONCLUSIONS}

The first irradiated production-scale metal waste ingot has been produced from treated cladding hulls using engineering-scale equipment located in the HFEF hot cell. Chemical analyses on the ingot provided data for both $\mathrm{Zr}$ and $\mathrm{U}$ in order to monitor product consistency and account for nuclear material, respectively. In addition, the noble metals were quantified and compared favorably to their fission yields within the error of the measurements. Immobilization of the noble metal fission products, as well as $\mathrm{U}$, was as expected, that is, primarily in the $\mathrm{Fe}-\mathrm{Zr}$ intermetallic phase. From a metal waste process perspective, 99.99 pct of the residual electrorefiner salt was removed from the cladding hulls prior to ingot consolidation. In addition, $\mathrm{Zr}$ was distributed sufficiently to verify acceptable operating parameters. Based on these results, the metal waste process produces homogeneous metal waste ingots as determined by both chemical and microscopic characterizations.

\section{ACKNOWLEDGMENTS}

The authors would like to acknowledge the Hot Fuel Examination Facility and Fuel Conditioning Facility operations personnel for their recent contributions and the Analytical Laboratory staff for chemical services. Given the extended history of metal waste form development, the following researchers at Argonne National Laboratory and the Idaho National Laboratory should also be recognized and this by no means represents a complete list: D.P. Abraham, J.P. Ackerman, R.W. Benedict, T.D. DiSanto, N.L. Dietz, W.L. Ebert, R.N. Elliott, T.H. Fanning, J.K. Fink, K.M. Goff, I. Johnson, S.G. Johnson, D.D. Keiser, Jr., C.J. Knight, J.R. Krsul, R.P. Lind, C.D. Morgan, E.E. Morris, S.M. McDeavitt, M. Noy, J.Y. Park, M.C. Petri, J.W. Richardson, Jr., D. Vaden, S. White, and R.A. Wigeland. This work was supported by the U.S. Department of Energy, Office of Nuclear Energy, Science, and Technology, under DOE-NE Idaho Operations Office Contract DE-AC07-05ID14517.

\section{REFERENCES}

1. C.E. Stevenson: The EBR-II Fuel Cycle Story, ANS, LaGrange Park, IL, 1987, pp. 85-119.

2. C.E. Till and Y.I. Chang: Plentiful Energy: The Story of the Integral Fast Reactor, CreateSpace, Charleston, SC, 2012.

3. Y.I. Chang: Nucl. Technol., 1990, vol. 88, pp. 129-38.

4. J.P. Ackerman, T.R. Johnson, and J.J. Laidler: Actinide Processing: Methods and Materials, TMS, Warrendale, PA, 1994, pp. 26166.

5. S.X. Li and M.F. Simpson: Min. Metall. Process., 2005, vol. 22, pp. $192-98$

6. S.X. Li, T.A. Johnson, B.R. Westphal, K.M. Goff, and R.W. Benedict: Proc. Global 2005, AESJ, Tsukuba, Japan, 2005.

7. D.D. Keiser, Jr. and R.D. Mariani: J. Nucl. Mater., 1999, vol. 270, pp. 279-89. 
8. S.M. McDeavitt, J.Y. Park, and J.P. Ackerman: Actinide Processing: Methods and Materials, TMS, Warrendale, PA, 1994, pp. 305-19.

9. B.R. Westphal, D.D. Keiser, R.H. Rigg, and D.V. Laug: Proc DOE Spent Nucl. Fuel: Chall. Initiatives, ANS, La Grange Park, IL, 1994, pp. 288-94.

10. D.P. Abraham, S.M. McDeavitt, and J.Y. Park: Metall. Trans. A, 1996, vol. 27A, pp. 2151-59.

11. S.M. McDeavitt, D.P. Abraham, D.D. Keiser, and J.Y. Park: Proc. Intl. Top. Manag. Nucl. Hazard. Waste Manag., ANS, La Grange Park, IL, 1996, pp. 2477-84.

12. S.M. McDeavitt, D.P. Abraham, D.D. Keiser, and J.Y. Park: Extraction and Processing for the Treatment and Minimization of Wastes, TMS, Warrendale, PA, 1996, p. 177.

13. D.P. Abraham, S.M. McDeavitt, and J.Y. Park: Proc. DOE Spent Nucl. Fuel Fissile Mater. Manag., ANS, LaGrange Park, IL, 1996, pp. 123-28.

14. D.D. Keiser, Jr. and S.M. McDeavitt: Proc. DOE Spent Nucl. Fuel Fissile Mater. Manag., ANS, LaGrange Park, IL, 1996, pp. 178-82.

15. S.M. McDeavitt, D.P. Abraham, J.Y. Park, and D.D. Keiser, Jr. JOM, 1997, vol. 49 (7), pp. 29-32.

16. D.P. Abraham, J.W. Richardson, Jr., and S.M. McDeavitt: Scripta Mater., 1997, vol. 37 (2), pp. 239-44.

17. D.P. Abraham, J.W. Richardson, Jr., and S.M. McDeavitt: Mater. Sci. Eng. A, 1997, vols. 239-240, pp. 658-64.

18. S.M. McDeavitt, D.P. Abraham, and J.Y. Park: J. Nucl. Mater. 1998, vol. 257, pp. 21-34.

19. D.D. Keiser, Jr. and B.R. Westphal: Proc. DOE Spent Nucl. Fuel Fissile Mater. Manag., ANS, LaGrange Park, IL, 1998, pp. 668-74.

20. D.P. Abraham and J.W. Richardson, Jr.: Long Term Stability of High Temperature Materials, TMS, Warrendale, PA, 1999, p. 169.

21. D.D. Keiser, Jr., D.P. Abraham, and J.W. Richardson, Jr.: J. Nucl. Mater., 2000, vol. 277, pp. 333-38.

22. D.D. Keiser, Jr., D.P. Abraham, W. Sinkler, J.W. Richardson, Jr., and S.M. McDeavitt: J. Nucl. Mater., 2000, vol. 279, pp. $234-44$.
23. D.P. Abraham and N. Dietz: Mater. Sci. Eng. A, 2002, vols. 329331, pp. 610-15.

24. D.E. Janney: MRS Proc., 2002, vol. 757, p. II3.5.

25. D.E. Janney: J. Nucl. Mater., 2003, vol. 323, pp. 81-92.

26. S.G. Johnson, D.D. Keiser, M. Noy, T. O'Holleran, and S.M Frank: MRS Proc., 1999, vol. 556, p. 953.

27. S.G. Johnson, D.D. Keiser, S.M. Frank, T. DiSanto, A.R. Warren, and M. Noy: MRS Proc., 1999, vol. 608, p. 589.

28. D.P. Abraham, L.J. Simpson, M.J. Devries, and S.M. McDeavitt: MRS Proc., 1999, vol. 556, p. 945.

29. R.W. Benedict, S.G. Johnson, D.D. Keiser, T.P. O'Holleran, K.M. Goff, S. McDeavitt, and W. Ebert: Proc. Plutonium Futures: Sci., AIP, Melville, NY, 2000, vol. 532, pp. 86-88.

30. S.G. Johnson, S.M. Frank, M. Noy, T. DiSanto, and D.D. Keiser, Jr.: Radioact. Waste Manag. Environ. Restor., 2002, vol. 22 (4), pp. 300-26.

31. S.G. Johnson, M. Noy, T. DiSanto, and T.L. Barber: MRS Proc., 2002, vol. 713, p. 73.

32. D.D. Keiser, Jr., S.G. Johnson, and W.L. Ebert: Proc. DOE Spent Nucl. Fuel Fissile Mater. Manag., ANS, LaGrange Park, IL, 2002.

33. S.G. Johnson, M. Noy, T. DiSanto, and D.D. Keiser: Proc. DOE Spent Nucl. Fuel Fissile Mater. Manag., ANS, LaGrange Park, IL, 2002.

34. K.C. Marsden, C. Knight, K. Bateman, B. Westphal, and P. Lind: Proc. Global 2005, AESJ, Tsukuba, Japan, 2005.

35. S.M. Frank, D.D. Keiser, Jr., and K.C. Marsden: Proc. Global 2007, ANS, LaGrange Park, IL, 2007, pp. 1404-11.

36. DOE M 470.4-6, Chg. 1, Nuclear Material Control and Accountability, 2006.

37. M.B. Chadwick, P. Oblozinsky, M. Herman, and N.M. Greene: Nucl. Data Sheets, 2006, vol. 107, pp. 2931-3060.

38. H. Kleykamp: Nucl. Technol., 1988, vol. 80, pp. 412-22.

39. W.M. Bowen and C.A. Bennett: Statistical Methods for Nuclear Materials Management (NUREG/CR-4604), U.S. Government Printing Office, Washington, DC, 1988. 